\title{
PEMAHAMAN GURU TENTANG PENDEKATAN SAINTIFIK DAN IMPLIKASINYA DALAM PENERAPAN PEMBELAJARAN DI SEKOLAH DASAR
}

\author{
Deti Rostika ${ }^{1}$ Prihantini $^{2}$ \\ Universitas Pendidikan Indonesia, Kampus Cibiru
}

\begin{abstract}
Implementation of the 2013 Curriculum essentially sets out three main things, namely the application of integrated thematic learning, the use of scientific approaches to learning, and authentic assessment. Some of the results of previous research on the implementation of the 2013 Curriculum, among others, found that teachers were less able to utilize learning resources from the surrounding environment and teachers tended to maintain conventional teaching habits. For this reason, through this study, researchers want to describe how teachers understand scientific approaches; how the teacher exposes the learning implementation plan; how the teacher applies the scientific approach to learning, and whether there is a contribution between the understanding of the scientific approach to the application of learning carried out by the teacher. The research method used is the Mixed Method Research model 'Embedded Design'. The results obtained from this study can be concluded that: (1) In general, teachers have understood the scientific approach, but have not understood how to implement this approach in learning in elementary schools; (2) Learning Implementation Plans (RPP) made by the teacher have not described learning activities oriented to the scientific approach; (3) Implementation of the implementation of learning carried out by the teacher has not reflected the application of the scientific approach; (4) Understanding the scientific approach contributes $10 \%$ to the implementation of learning. Therefore, being able to apply a scientific approach is not only determined by understanding, but it requires the efforts of teachers to always seek other knowledge that can add to and improve self-efficacy
\end{abstract}

Keyword: scientific approach, thinking skills and scientific work, Mixed method research embedded models

\begin{abstract}
Abstrak: Implementasi Kurikulum 2013 pada intinya menetapkan tiga hal utama, yaitu penerapan pembelajaran tematik terpadu, penggunaan pendekatan saintifik dalam pembelajaran, dan penilaian autentik. Beberapa hasil penelitian terdahulu tentang implementasi Kurikulum 2013, antara lain ditemukan bahwa guru kurang mampu memanfaatkan sumber-sumber belajar dari alam sekitar dan guru cenderung mempertahankan kebiasaan mengajar konvensional. Untuk itu melalui penelitian ini, peneliti ingin mendeskripsikan bagaimana pemahaman guru terhadap pendekatan saintifik; bagaimana guru membuar rencana pelaksanaan pembelajaran; bagaimana guru menerapkan pendekatan saintifik dalam pembelajaran, dan apakah ada kontribusi antara pemahaman pendekatan saintifik terhadap penerapan pembelajaran yang dilaksanakan guru. Metode penelitian yang digunakan adalah Mixed Method Research model 'Embedded Design'. Hasil yang diperoleh dari penelitian ini dapat disimpulkan bahwa: (1) Pada umumnya guru telah memahami pendekatan saintifik, tetapi belum memahami cara mengimplementasikan pendekatan tersebut dalam pembelajaran di Sekolah Dasar; (2) Rencana Pelaksanaan Pembelajaran (RPP) yang dibuat guru belum menggambarkan kegiatan-kegiatan pembelajaran yang berorientasi pada pendekatan saintifik; (3) Implementasi pelaksanaan pembelajaran yang dilaksanakan guru belum mencerminkan pada penerapan pendekatan saintifik; (4) Pemahaman pendekatan saintifik berkontribusi $10 \%$ terhadap implementasi pelaksanaan pembelajaran. Oleh karena itu untuk bisa menerapkan pendekatan saintifik tidak hanya ditentukan oleh pemahaman, tetapi
\end{abstract}

\footnotetext{
' Universitas Pendidikan Indanesia, Kampus Cibiru, Email: derasti国upi.edu

${ }^{2}$ Universitas Pendidikan Indanesia, Kampus Cibiru, Email: prihantini|⿴囗玉 upi.edu
} 
diperlukan upaya guru untuk selalu mencari pengetahuan lain yang dapat menambah dan meningkatkan efikasi diri.

Kata Kunci: pendekatan saintifik, keterampilan berpikir dan kerja ilmiah, Mixed method research embedded model.

\section{PENDAHULUAN}

Guru sebagai agen pembelajaran konsekuensinya harus memiliki kepiawaian, dan kewibawaan dalam melangsungkan proses pembelajaran. Kepiawaian dan kewibawaan guru, salah satunya ditentukan oleh penguasaan pendekatan pembelajaran, untuk dapat mengantar peserta didik mencapai tujuan pendidikan. Arends (2013) mengatakan, bahwa guru yang efektif memiliki kemampuan dalam tiga hal, dasar pengetahuan luas berkaitan dengan bidang studi, pengembangan manusia dan pembelajaran, serta pedagogi.

Guru piawai dan wibawa adalah guru intensional, yakni guru yang selalu berupaya untuk terus menerus memikirkan praktik pembelajaran, dan hasil yang diperoleh dari pembelajaran. Hasil riset ditemukan, bahwa salah satu alat yang paling ampuh memprediksi dampak pembelajaran yang dilakukan guru pada peserta didik, adalah keyakinan yang guru kerjakan menghasilkan sesuatu yang berbeda. Keyakinan tersebut merupakan teacher efficacy (Slavin, 2011, hlm 9), yang mengacu pada persepsi guru tentang kemampuan diri untuk melakukan tugas dan keyakinan, bahwa dirinya memiliki keterampilan melakukan sesuatu secara maksimal, untuk menghasilkan tujuan yang diinginkan (Posnanski, 2002). Oleh karena itu guru yang memiliki self efficacy tinggi, selalu mencoba menerapkan pendekatan pembelajaran untuk dapat mengantarkan peserta didik memiliki kompetensi, baik sikap, pengetahuan, maupun keterampilan.

Pendekatan pembelajaran saintifik merupakan titian emas bagi perkembangan dan pengembangan sikap, keterampilan, dan pengetahuan peserta didik (Rusman, 2017). Melalui pendekatan saintifik diyakini dapat memberikan keterampilan berfikir (thinking skills) peserta didik menghadapi masalah dalam kehidupan (Salim, 2014). Sejumlah hasil penelitian terdahulu tentang implementasi Kurikulum 2013, antara lain ditemukan bahwa guru kurang mampu memanfaatkan sumbersumber belajar dari alam sekitar dan guru cenderung mempertahankan kebiasaan mengajar konvensional (Kuntarto, 2014). Ruja dan Sukamto (2013) dalam survey permasalahan implementasi kurikulum 2013 ditemukan guru masih mengalami kesulitan dalam membuat Rencana Pelaksanaan Pembelajaran (RPP). Rumahlatu, dkk (2016) melalui penelitian an analysis of the Readiness and Implementation of 2013 Curriculum menghasilkan temuan "the mental readiness of teachers and students which are not yet optimally prepared". Hasil penelitian Budiyanto, dkk (2016) tentang implementasi pendekatan saintifik dalam pembelajaran di pendidikan dasar di Malang diperoleh kesimpulan bahwa ada perbedaan implementasi pendekatan saintifik dalam pembelajaran Guru di SD dan SMP.

Untuk itu melalui penelitian ini, peneliti ingin mendeskripsikan bagaimana pemahaman guru terhadap pendekatan saintifik. Dari pemahaman yang dimiliki akan diteliti pula bagaimana guru menyusun rencana pelaksanaan pembelajaran (RPP), bagaimana guru menerapkan pendekatan saintifik dalam pembelajaran, dan apakah pemahaman pendekatan saintifik berkontribusi terhadap penerapan pembelajaran yang dilaksanakan guru. 
PENDEKATAN SAINTIFIK DALAM PEMBELAJARAN

\section{A. Hakekat Pendekatan Pembelajaran}

Hosnan (2014, hlm 32),

berpendapat bahwa pengertian pendekatan adalah: (1) proses, perbuatan, cara mendekati, (2) usaha dalam rangka aktivitas pengamatan untuk mengadakan hubungan dengan orang yang diteliti, metode-metode untuk mencapai pengertian tentang masalah pengamatan. Pendapat lain mendefinisikan pendekatan pembelajaran sebagai latar pedagogis dan psikologis yang dilandasi filosofi pendidikan tertentu yang dipilih agar tujuan pembelajaran dapat tercapai atau dapat didekati secara optimal (Suyono dan Hariyanto, 2015 hlm 54). Sedangkan pendapat Abidin (2014, hlm 110) bahwa pendekatan pembelajaran dipandang sebagai ' $a$ way of beginning something' atau cara memulai sesuatu. Sesuai dengan istilah yang dikemukakan Abidin, pendekatan pembelajaran merupakan titik tolak atau sudut pandang terhadap proses pembelajaran, yang merujuk pada pandangan tentang terjadinya suatu proses yang sifatnya masih sangat umum, didalamnya mewadahi, menginspirasi, mengautkan, dan melatari metode pembelajaran (Komalasari, 2013 hlm 54).

\section{B. Hakekat Pendekatan Saintifik}

Ditinjau dari klasifikasi pendekatan, pendekatan saintifik termasuk dalam student centered approach, karena dalam prosesnya lebih mengutamakan peserta didik yang aktif dalam proses pembelajaran dan guru berperan sebagai fasilitator. Dari sudut tinjauan proses, pendekatan saintifik merupakan pendekatan pembelajaran yang berorientasi pada langkah-langkah kerja ilmiah. Ryan, M dan O'Callaghan (2018) mengemukakan pendapat tentang pendekatan saintifik, yakni:

The Scientific Method is a process used to validate observations while minimizing observer bias. Its goal is for research to be conducted in a fair, unbiased and repeatable manner.
Langkah kerja ilmiah berdasarkan definisi di atas terdapat dalam kegiatan observasi dan validasi terhadap hasil observasi. Hosnan (2014, hlm 34) mengemukakan bahwa pendekatan saintifik dimaksudkan untuk memberikan pemahaman kepada peserta didik dalam mengenal, memahami berbagai materi dengan menggunakan pendekatan ilmiah, untuk mendapat informasi dari berbagai sumber dalam mencari tahu, baik melalui observasi maupun penelitian. Pendapat yang lebih menegaskan bahwa pendekatan saintifik dalam pembelajaran berorientasi pada langkah kerja ilmiah sesuai dengan pendapat Sufairoh (2016).

Proses pembelajaran yang dirancang sedemikian rupa agar peserta didik secara aktif mengkonstruk konsep, hukum atau prinsip melalui tahapantahapan mengamati (untuk mengidentifikasi atau menemukan masalah), merumuskan masalah, mengajukan atau merumuskan hipotesis, menganalisis data, menarik kesimpulan, dan mengkomunikasikan konsep, hukum atau prinsip yang ditemukan.

Pendapat Rusman (2017, hlm 422) bahwa pendekatan saintifik adalah sebuah pendekatan pembelajaran yang menekankan pada aktivitas peserta didik melalui kegiatan mengamati, menanya, menalar, mencoba, dan membuat jejaring pada kegiatan pembelajaran di sekolah. Mencermati peraturan dan pendapat Rusman tersebut, maka pada dasarnya pendekatan saintifik dalam pembelajaran adalah serangkaian kegiatan dalam proses pembelajaran yang menerapkan langkahlanglah kerja ilmiah. Sesuai peraturan yang berlaku, 5 M (mengamati, menanya, menalar, mencoba, dan mengkomunikasikan) tidak selamanya harus sesuai urutan, tetapi dapat dimodifikasi selama dalam proses menunjukkan adanya kerja ilmiah. Hal ini dapat dikatakan bahwa model-model pembelajaran yang didalamnya memiliki karakteristik syntax kerja ilmiah merupakan model pembelajaran 
berorientasi kerja ilmiah atau termasuk model pembelajaran berorientasi pendekatan saintifik.

\section{Penerapan Pendekatan Saintifik dalam Pembelajaran}

Penerapan pendekatan saintifik dalam pembelajaran pada dasarnya berpedoman pada karakteristik pendekatan saintifik yang ditransformasikan dalam langkah-langkah pembelajaran. Langkah penerapan pendekatan saintifik menurut Ryan dan O'Callaghan (2018, hlm 3) meliputi lima langkah sebagai berikut STEP 1: Make an OBSERVATION gather and assimilate information about an event, phenomenon, process, or an exception to a previous observation, etc.

STEP 2: Define the PROBLEM - ask questions about the observation that are relevant and testable. Define the null hypothesis to provide unbiased results.

STEP 3: Form the HYPOTHESIS - create an explanation, or educated guess, for the observation that is testable and falsifiable.

STEP 4: Conduct the EXPERIMENT devise and perform an experiment to test the hypothesis.

STEP 5: Derive a THEORY - create a statement based in the outcome of the experiment that explains the observation(s) and predicts the likelihood of future observations.

Berdasarkan Peraturan Menteri Pendidikan dan Kebudayaan Nomor 22 Tahun 2016, disebutkan langkah pembelajaran dengan pendekatan saintifik meliputi mengamati, menanya, mencoba, menalar (mengasosiasi), menyimpulkan, serta mengkomunikasikan (membentuk jejaring). Lima langkah ini dikenal dengan istilah 5M. Penjelasan lebih rinci adalah sebagai berikut.

1. Mengamati

Mengamati merupakan kegiatan yang disengaja dan sistematis tentang fenomena sosial, gejala-gejala alam, atau isu-isu kehidupan. Proses pembelajaran yang dapat dilaksanakan pada langkah ini adalah membaca, mendengar, menyimak, melihat (tanpa atau dengan alat) atau mengamati secara langsung fakta, peristiwa, atau suatu proses percobaan.

2. Menanya

Menanya dalam proses belajar pada hakikatnya adalah bertanya untuk memperoleh jawaban berdasarkan rasa ingin tahu. Dalam kegiatan ini peserta didik dilatih untuk merumuskan pertanyaan, yang dapat diproses melalui mengajukan pertanyaan atau merumuskan pertanyaan terhadap apa yang diamati, dibaca, atau didengar.

3. Menalar

Menalar merupakan suatu proses berpikir logis untuk memperoleh pengetahuan. Menalar dalam konteks pendekatan saintifik merujuk pada kemampuan mengelompokkan beragam ide dan mengasosiasikan beragam peristiwa. Kegiatan pada langkah ini dapat dimaknai sebagai kegiatan mengolah informasi yang diperoleh dari kegiatan sebelumnya. Pada langkah ini peserta didik diproses untuk memperluas atau memperdalam sejumlah informasi yang sudah diperoleh pada kegiatan sebelumnya. Pada kegiatan ini peserta didik diproses untuk memiliki sikap jujur, teliti, disiplin, taat aturan, kerja keras, menerapkan prosedur, dan berpikir induktif maupun deduktif.

4. Mencoba

Kegiatan pada langkah ini adalah melakukan eksperimen. Namun demikian langkah eksperimen ini dapat dilaksanakan alternatif kegiatan lain, yaitu dapat berbentuk kegiatan membaca sumber lain selain buku teks, menganalisis suatu peristiwa atau kejadian, atau melakukan wawancara dengan nara sumber. Melalui kegiatan ini peserta didik diarahkan memiliki kompetensi teliti, jujur, sopan, menghargai pendapat orang lain, menerapkan keterampilan analisis dan sintesis melalui berbagai cara terhadap materi yang dipelajari.

5. Mengkomunikasikan

Pada langkah ini peserta didik harus menyampaikan hasil pengamatan, dan menyampaikan kesimpulan berdasarkan 
hasil percobaan atau analisis. Penyampaian kesimpulan dapat melalui komunikasi secara lisan, tertulis, atau media lainnnya dalam bentuk produk. Produk dapat berupa essay, poster, maket atau miniatur suatu obyek, atau bentukbentuk produk lain. Kegiatan mengkomunikasikan bertujuan untuk mengembangkan peserta didik memiliki sikap jujur, teliti, toleransi, terlatih kemampuan menyampaikan hasil pemikiran secara sistematis, mengungkapkan pendapat dengan singkat dan jelas, dan mengembangkan kemampuan berbahasa yang baik dan benar baik secara lisan maupun tertulis.

\section{METODOLOGI PENELITIAN}

Penelitian ini menggunakan Mixed Method Research model 'Embedded Design'. Embedded Design model yang dipilih adalah embedded correlation design model. Lokasi penelitian ditetapkan di Kota Bogor. Lokasi penelitian ditetapkan melalui pertimbangan latar belakang wilayah perkotaan yang akses ke ibukota dekat, dengan alasan bahwa kota yang dekat dengan ibukota Negara diasumsikan lebih sering, dan mudah mengakses informasi perkembangan terkini inovasi pembelajaran. Populasi meliputi seluruh SD yang ada di wilayah Kota Bogor, dan sampel penelitian meliputi empat SD, dua SD merupakan pilot implementasi Kurikulum 2013 yang ditetapkan oleh Pemerintah, dan dua SD merupakan sekolah yang secara mandiri mengimplementasikan Kurikulum 2013. Pengambilan sampel digunakan teknik purposive random sampling. Teknik pengumpulan data pada penelitian ini menggunakan angket, observasi kelas, studi dokumen, dan in-depth inverview.
HASIL PENELITIAN

DAN PEMBAHASAN

\section{A. Pemahaman Guru tentang Pendekatan Saintifik}

Hasil pengisian kuesioner yang terdiri dari 30 item pernyataan oleh 20 orang responden, diperoleh data bahwa skor di atas rata-rata diperoleh empat orang guru, terdiri dari 1 orang responden memperoleh jumlah skor 145 dan 3 orang guru memperoleh jumlah skor 143. Skor rata-rata 130,55 diperoleh 15 orang guru, dan skor lebih kecil dari rata-rata diperoleh satu orang guru dengan jumlah skor 120. Persentase perolehan skor responden dapat ditunjukkan melalui grafik berikut.

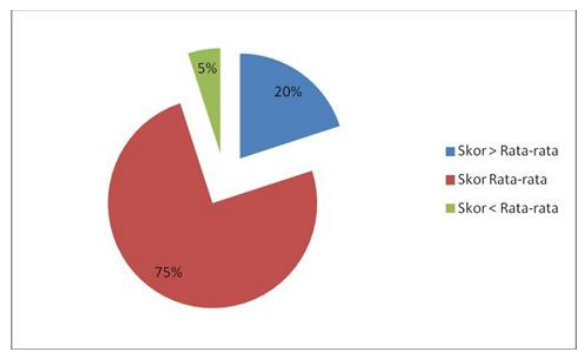

Gambar 1. Persentase Perolehan Skor Responden tentang Pemahaman Pendekatan Saintifik

Gambar di atas menunjukkan bahwa dari 20 responden, $75 \%$ memperoleh skor rata-rata, $20 \%$ memperoleh skor di atas rata-rata, dan 5\% memperoleh skor di bawah rata-rata. Untuk memperkuat hasil analisis data kuantitatif tersebut, perlu didukung data kualitatif sesuai dengan tujuan penelitian untuk memperoleh gambaran yang komprehensif dari hasil penelitian. Dengan pertimbangan tersebut, maka peneliti melaksanakan wawancara mendalam kepada responden, dengan tujuan untuk memperoleh pengetahuan yang sebenarnya tentang pemahaman pendekatan saintifik. Hasil wawancara merupakan data kualitatif seperti tercantum pada Tabel 1. 
Tabel 1. Data kualitatif hasil wawancara

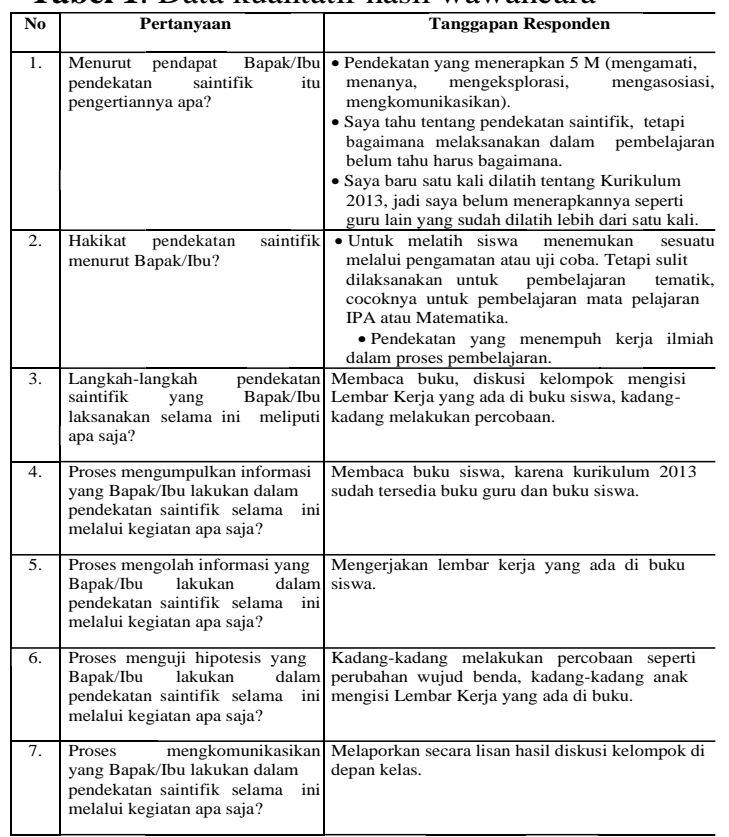

Berdasarkan tabel tersebut bahwa responden secara umum memahami hakikat pendekatan saintifik, namun menurut pengakuan mereka belum sepenuhnya menerapkan langkah-langkah kegiatan saintifik dalam pembelajaran. Hal ini teridentifikasi dari pengakuan mereka bahwa: (1) memahami pengertian tetapi belum memahami cara menerapkan, (2) kegiatan belajar siswa yang diciptakan guru pada umumnya masih monoton dengan membaca buku dan mengisi lembar kerja dalam kelompok, (3) mengalami kesulitan menerapkan pendekatan saintifik dalam pembelajaran tematik, (4) keterampilan berkomunikasi peserta didik hanya sebatas melaporkan hasil pengisian lembar kerja di depan kelas, (5) ada satu orang responden yang mengaku baru satu kali mengikuti pelatihan kurikulum 2013, sehingga belum mampu menerapkan pendekatan saintifik.

\section{B. Penerapan Pendekatan Saintifik dalam Pembelajaran}

Untuk memperoleh data tentang penerapan pendekatan saintifik dalam pembelajaran, dilaksanakan observasi proses pembelajaran bagi 20 orang guru. Instrumen observasi dibuat dalam bentuk skala, yakni skala 1 sampai dengan 5 yang terdiri dari 17 item. Perolehan skor 20 responden berdasarkan hasil observasi diilustrasikan melalui grafik berikut.

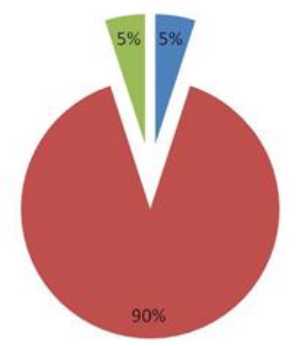

- Skor $>$ Rata-rata

m Skor Rata-rata

m $=$ Skor $<$ Rata-rata

Gambar 2. Persentase Perolehan Skor Penerapan Pendekatan Saintifik dalam Pembelajaran

Memperhatikan grafik di atas dapat dideskripsikan sebagai berikut. Skor di atas rata-rata diperoleh satu orang guru yang menerapkan pendekatan saintifik dalam pembelajaran secara sistematis, dengan menerapkan model pembelajaran inquiry untuk menemukan rumus luas bangun kubus. Skor rata-rata diperoleh 18 orang guru yang mengimplementasikan pendekatan saintifik hanya beberapa aktivitas pembelajaran, yakni pengamatan melalui membaca buku teks, menganalisis masalah melalui diskusi kelompok, mengerjakan lembar kerja, dan melaporkan hasil diskusi kelompok di depan kelas. Aktivitas pembelajaran yang terarah pada merumuskan pertanyaan, melakukan eksperimen, dan menghasilkan produk tidak dilaksanakan guru. Skor terendah diperoleh satu orang guru, hasil observasi menunjukkan guru tersebut tidak menerapkan pendekatan saintifik.

\section{Dokumem Rencana Pelaksanaan Pembelajaran}

Analisis 20 dokumen Renacana Pelaksanaan Pembelajaran (RPP) dari 20 responden yang diobservasi proses pembelajarannya, diperoleh hasil bahwa terdapat tujuh RPP teridentifikasi memuat rencana kegiatan guru dan kegiatan siswa sesuai dengan langkah-langkah pendekatan saintifik. Terdapat 10 RPP yang memuat rencana kegiatan pendekatan saintifik, tetapi tidak lengkap dan hanya beberapa kegiatan yang terencanakan. Tiga orang responden mengajar tanpa membuat RPP. 


\section{Kontribusi Pemahaman Guru tentang Pendekatan Saintifik terhadap Penerapan Pembelajaran}

Kontribusi pemahaman guru tentang pendekatan saintifik terhadap implementasi pembelajaran, dianalisis menggunakan rumus Spearman rho dengan menerapkan aplikasi SPSS 19. Hasil pengolahan seperti terlihat pada tabel berikut.

Tabel 2. Kontribusi Pemahaman Pendekatan Saintifik terhadap Penerapan Pembelajaran Correlations

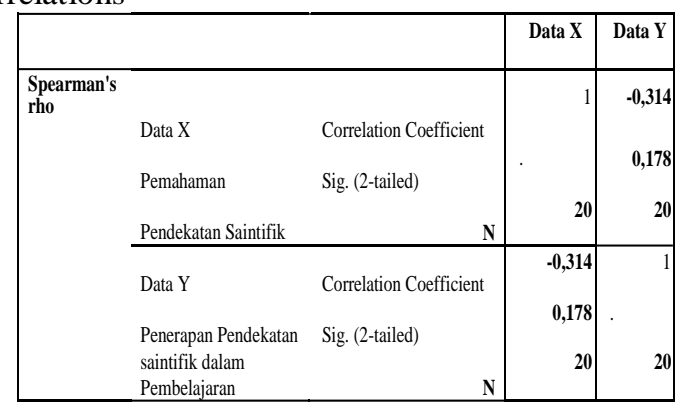

Berdasarkan tabel di atas menunjukkan bahwa angka korelasi ditemukan -0,314, angka perolehan lebih kecil dari signifikansi (2-tailed) yang menunjukkan angka 0,178. Dengan demikian Ho diterima, yakni tidak ada kontribusi pemahaman guru tentang pendekatan saintifik terhadap implementasi pembelajaran di SD.

Untuk memastikan apakah pemahaman tentang pendekatan saintifik berkontribusi terhadap implementasi pembelajaran maka diuji dengan $\mathrm{r}^{2}$ ($0,314)^{2}=0,10$. Hal ini dapat diartikan bahwa kontribusi pemahaman pendekatan saintifik terhadap implementasi pembelajaran adalah 10 persen.

\section{Pembahasan.}

\section{A. Pemahaman Guru tentang Pendekatan Saintifik}

Berdasarkan analisis data terbukti bahwa sebagian besar guru, yakni mencapai $75 \%$ jumlah guru memahami pendekatan saintifik. Namun demikian berdasarkan hasil wawancara, mereka mengaku tahu hakikat pendekatan saintifik, tetapi belum memahami cara menerapkannya dan menyatakan kesulitan menerapkan pendekatan saintifik dalam pembelajaran tematik. Pernyataan lain dari guru, selama ini kegiatan peserta didik dalam pembelajaran adalah kerja kelompok mengisi lembar kerja (LK). Demikian pula dalam mengembangkan keterampilan berkomunikasi, peserta didik biasanya ditugaskan untuk melaporkan hasil pengisisn lembar kerja di depan kelas.

Temuan lain terdapat satu orang responden yang mengaku baru satu kali mengikuti pelatihan kurikulum 2013, sehingga belum mampu menerapkan pendekatan saintifik. Hal ini menunjukkan bahwa pelatihan guru tentang Kurikulum 2013 belum merata. Sementara guru yang bersangkutan, walaupun belum mengikuti pelatihan tidak berusaha mencari tahu kepada koleganya yang telah mengikuti pelatihan. Hal ini menunjukkan bahwa guru tersebut tidak membuka diri terhadap adanya perubahan. Temuan tersebut sesuai dengan hasil penelitian Retnawati, $\mathrm{H}$ dkk (2006) dan Rumahlatu dkk (2016), bahwa banyak guru yang bingung, ragu-ragu, dan tidak membuka diri menerima perubahan, dan belum siap menerima perubahan dengan adanya Kurikulum 2013.

\section{B. Penerapan Pendekatan Saintifik dalam Pembelajaran}

Mengacu pada analisis data hasil observasi proses pembelajaran menunjukkan, bahwa pada umumnya guru menerapkan pendekatan saintifik dalam pembelajaran, tetapi belum mengikuti langkah-langkah pendekatan saintifik secara sistematis. Persentase guru yang telah menerapkan pendekatan saintifik hanya mencapai $5 \%$, sementara yang tidak menerapkan pendekatan saintifik juga mencapai $5 \%$.

Hasil pengamatan proses pembelajaran sesuai dengan pengakuan guru ketika diwawancarai, bahwa yang 
diterapkan dalam pembelajaran baru sebatas kerja kelompok mengisi lembar kerja dan membaca buku teks yang tersedia di sekolah. Guru belum mencoba untuk menerapkan kegiatan belajar yang lain, yang dapat membuat peserta didik aktif melakukan aktivitas kerja ilmiah. Apabila dihubungkan dengan pemahaman yang dimiliki guru tentang pendekatan saintifik, dapat disimpulkan bahwa guru-guru baru sampai pada sebatas "tahu" hakikat pendekatan saintifik, tetapi belum memiliki pemahaman untuk menerapkan. Hal ini menunjukkan, bahwa pengetahuan yang telah dimiliki guru tentang pendekatan saintifik, tidak diikuti dengan usaha untuk menerapkan. Demikian pula, ketika sudah memiliki pengetahuan seharusnya memiliki persepsi, dan keyakinan mampu menerapkan, atau disebut dengan memiliki efikasi diri (self efficacy).

\section{Analisis Dokumen RPP}

Hasil analisis dokumen RPP ditemukan bahwa belum semua guru menyusun RPP dengan benar. Dari sejumlah dokumen yang telah dianalisis, hanya tujuh RPP yang penyusunannya sesuai dengan langkah-langkah pendekatan saintifik. Ditemukan pula ada tiga orang guru yang mengajar tanpa berpedoman pada RPP, dan guru tersebut tidak memiliki dokumen RPP untuk melaksanakan pembelajaran saat itu. Temuan penelitian ini telah dibuktikan oleh peneliti terdahulu (Ruja dan Sukamto, 2013) bahwa guru masih mengalami kesulitan dalam membuat Rencana Pelaksanaan Pembelajaran (RPP).

Langkah yang harus direncanakan untuk mengimplementasikan pendekatan saintifik adalah mengamati, menanya dalam hal ini merumuskan pertanyaan atau hipotesa, melakukan percobaaan atau mengumpulkan data dengan cara lain, menganalisa atau mengasosiasi, dan melaporkan secara lisan atau tertulis (Rusman, 2017). Berdasarkan data hasil analisis dokumen RPP dapat dikatakan, bahwa guru dalam menyusun perencanaan pembelajaran belum menetapkan aktivitas belajar yang harus dilakukan peserta didik untuk dapat mencapai tujuan pembelajaran secara optimal (Suyono dan Hariyanto, 2015, Musfiqon dan Nurdyansyah, 2015).

\section{Kontribusi Pemahaman Pendekatan Saintifik terhadap Penerapan Pembelajaran}

Berdasarkan hasil analisis data sebagaimana terlihat pada tabel 2 , analisis korelasi menggunakan rumus Spearman rho ditemukan -0,314. Untuk memastikan apakah pemahaman tentang pendekatan saintifik berkontribusi terhadap implementasi pembelajaran maka diuji dengan $r^{2}(0,10)$. Hal ini dapat diartikan bahwa kontribusi pemahaman pendekatan saintifik terhadap implementasi pembelajaran adalah 10 persen.

Dengan demikian dapat disimpulkan bahwa kemampuan mengimplementasikan pendekatan saintifik dalam proses pembelajaran, tidak hanya ditentukan oleh faktor pemahaman tetapi juga faktor-faktor lain. Hal ini sesuai dengan pendapat Slavin (2011) bahwa seorang guru harus memiliki efikasi diri untuk menjadi guru intensional.

\section{KESIMPULAN}

Kesimpulan dari hasil penelitian bahwa pada umumnya guru telah memahami pendekatan saintifik, tetapi belum memahami cara mengimplementasikan pendekatan tersebut dalam pembelajaran di Sekolah Dasar. Rencana Pelaksanaan Pembelajaran (RPP) yang dibuat guru belum menggambarkan kegiatan-kegiatan pembelajaran yang berorientasi pada pendekatan saintifik. Implementasi pelaksanaan pembelajaran yang dilaksanakan guru belum mencerminkan pada penerapan pendekatan saintifik. Pemahaman pendekatan saintifik berkontribusi $10 \%$ terhadap implementasi pelaksanaan pembelajaran. 
DAFTAR PUSTAKA

Abidin, Y. (2014). Desain Sistem Pembelajaran Dalam Konteks Kurikulum 2013. Bandung: Refika Aditama.

Arends, RI. (2013). Belajar Untuk Mengajar. Jakarta: Salemba

Budiyanto, M.A.K, et. al. (2016) Implementation of Scientific Approach in Education in Primary Education in Malang [22 Okt 2018] Available from Proceeding Biology Education Conference (ISSN:25285742), Vol 13 (1) 2016: 46-51.

Hosnan, M. (2014). Pendekatan Saintifik dan Kontekstual dalam Pembelajaran Abad 21 Kunci Sukses Implementasi. Bogor: Ghalia Indonesia.

Komalasari, K. (2013). Pembelajaran Kontekstual Konsep dan Aplikasi. Bandung: Refika Aditama.

Kuntarto, E. (2014). Kajian Implementasi Kurikulum 2013 pada Pembelajaran Calistung di SD. Universitas Jambi: FKIP Prodi PGSD

Musfiqon dan Nurdyansyah. (2015). Pendekatan Pembelajaran Saintifik. Sidoarjo: Nizamia Learning Center.

Posnanski, T. J. (2002). Professional Development Programms for Elementary Science Teachers: An Analysis of Teacher Self Efficacy Beliefes and a Professional Development Model [cited 22 Nov 2018]; Available from Journal of Science Teacher Education, 13(2): 189-220.2002.

Retnawati, H. et.al. (2006). Teachers'Difficulties in Implementing Thematic Teaching and Learning in Elementary Schools. [cited 20 Oct 2018] Available from http:educationalrev.us.edu.pl.

Ruja \& Sukamto. (2013). Survey Permasalahan Implementasi Kurikulum Nasional 2013 Mata Pelajaran IPS SMP di Jawa Timur. Universitas Negeri Malang.
Rumahlatu, D., Huliselan, E.K., \& Takaria, J. (2016). An Analysis of the Readiness and Implementation of 2013 Curriculum in the West Part of Seram District, Maluku Province, Indonesia. International Journal of Environmental and Science Education 11 (12), 5662-5675

Rusman. (2017) Belajar \& Pembelajaran Berorientasi Standar Proses Pendidikan Jakarta: Prenadamedia Group.

Ryan, M \& O'Callaghan. (2018). A The Scientific Method University of Nevada [cited 22 Nov 2018]; Available from http://unce.unr.edu/ publication/pdf.

Salim, Z. A. (2014) The Effect of Using Socio-Scientific Issues Approach in Teaching Environmental Issues on Improving the Students Ability of Making Appropriate Decisions Towards these Issues [cited 22 Nov 2018]; Available International Education Studies; Vol 7, No.8; 2014 ISSN 1913-9020 E-ISSN 1913-9039 Canadian Center of Science and Education.

Slavin, R.E. (2011). Pearson Internasional Edition Educational Psychology Theory and Practice. Ccolumbus Ohio: Pearson.

Sufairoh. (2016). Pendekatan Saintifik \& Model Pembelajaran K-13. Jurnal Pendidikan Profesional, Volume 5 No. 3 Desember 2016 hal 116.

Suyono \& Hariyanto. (2015). Implementasi Belajar Pembelajaran. Surabaya: Remaja Rosdakarya 